Health Foundation, London, UK

Hugh.Alderwick@health.org.uk Cite this as: BMJ 2022;376:051 http://dx.doi.org/10.1136/bmj.051 Published: 11 January 2022

\section{Is the NHS overwhelmed?}

\section{Millions of people are already feeling the effects of a health system under unbearable strain Hugh Alderwick head of policy}

Finding the right words to describe the pressures facing healthcare services in England right now is difficult. They are certainly not normal: at least 24 NHS trusts declared a "critical incident" in the first week of January, ${ }^{1}$ which means they may not be able to provide urgent or safe services. ${ }^{2}$ In November 2021, 10 ooo patients waited over 12 hours in emergency departments after a decision to admit to hospital-five times more than in $\mathbf{2 0 2 0}$ and nine times more than in 2019. ${ }^{3}$ Since then, covid-19 cases have spiked, ${ }^{4}$ and staff absences in hospital are up by around 40\%. ${ }^{5}$

But is the NHS overwhelmed? The British Medical Association says so: "the facts, figures, and the living reality for thousands of patients and NHS staff daily demonstrate undoubtedly that the NHS is currently already overwhelmed." ${ }^{6}$ But the prime minister is not so sure: "different places, at different moments, will feel at least temporarily overwhelmed," he said last week. ${ }^{6}$ Just not enough-yet-to warrant further measures to control covid-19 cases.

Protecting the NHS from being overwhelmed has been a government priority throughout the pandemic. ${ }^{7-9}$ This has often been interpreted as the number of people in hospital and the capacity, such as numbers of beds, available to treat them..$^{10}$ But there is no clear definition of an overwhelmed healthcare system, despite the risk of it happening looming large in the political psyche.

One version might be when a healthcare system cannot provide care to people who need it. Reports from Italy in March 2020 of patients lying in hospital corridors and shortages of ventilators offered a distressing example of what this looks like. ${ }^{11}$ But less extreme forms are pervasive and harmful: many countries postponed planned services during the pandemic and some reduced emergency care. ${ }^{12-14}$ In the NHS, covid-19 led to a massive disruption of care and a huge backlog of unmet need, including six million people now waiting for routine hospital treatment. ${ }^{15}$ Rationing in the NHS is nothing new ${ }^{16}$ and has helped the system deal with covid-19 pressures. But when does rationing reflect not coping?

Another version of "overwhelmed" might be when quality of care falls below an acceptable threshold. Staff shortages in the NHS stood at 100 ooo before covid-19. ${ }^{17}$ Now more than 80 ooo hospital staff are also off sick or self-isolating-around half because of covid-19. ${ }^{5}$ Patient safety is at risk. ${ }^{18} 19$ The army has been called in to help London hospitals. ${ }^{20}$ And people are being asked to find lifts to emergency departments because ambulances are taking so long to arrive. ${ }^{21}$
What measures can tell us when things have gone from bad to overwhelmed? In the NHS constitution, government sets out various performance standards for NHS care and rights for patients, such as the right to start non-urgent consultant-led treatment within 18 weeks from referral..$^{22}$ In October 2021, more than two million people had waited longer than 18 weeks for routine hospital treatment-and more than 300 ooo people had waited more than a year. ${ }^{3}$ Access to care fell furthest in the most deprived areas during the pandemic. ${ }^{23}$ But poor performance predated covid-19: the NHS has missed key national targets on cancer, planned, and emergency care for several years. ${ }^{3}$ Has the NHS been overwhelmed this whole time?

Perhaps being overwhelmed is more of a feeling. After nearly two years of the pandemic, NHS staff are exhausted and almost half report illness from work related stress. ${ }^{24}$ Some have experienced severe moral and psychological distress. ${ }^{25}{ }^{26}$ Recent public polling suggests that one in four people are not confident in the NHS's ability to provide the care they need. ${ }^{27}$

The Oxford English Dictionary offers various definitions of overwhelmed, including "sudden ruin or destruction.” But looking for a single moment when the NHS goes up in smoke misses the point. Millions of patients and staff are already feeling the negative effects of a healthcare system struggling to cope with the unbearable demands placed on it. This will not be a short term phenomenon: government has provided insufficient funding to clear the backlog of unmet care ${ }^{28}$ and the NHS has no long term plan to deal with staff shortages.

Looking for a single definition also misses the point. Different healthcare systems have different starting points, values, and expectations-and these change over time. Going into the pandemic, the UK had fewer doctors and hospital beds per capita than most comparable countries. Germany, meanwhile, had high levels of both. ${ }^{1329}$ Yet both countries have been high spenders on their health system response to covid-19 compared with other European countries. ${ }^{13}$ These and other factors, like political leadership and public health measures, ${ }^{30}$ have affected the ability of healthcare systems to cope with covid-19. Longstanding underfunding and neglect of social care in England has also had an effect. ${ }^{31}$

The prime minister has suggested England can "ride out" the latest wave of covid-19 infections without introducing further covid-19 measures. ${ }^{6}$ He faces pressure from his own MPs to avoid more restrictions ${ }^{32}$ and relied on Labour votes to introduce the relatively modest policy measures already in place. This is ultimately a political gamble-and 


\section{government must be honest about the consequences for the NHS and the public it serves.}

Competing interests: I have read and understood BMJ policy on declaration of interests and have no interests to declare.

Provenance and peer review: Commissioned; not externally peer reviewed.

1 Allegretti A. At least 24 NHS trusts declare critical incidents due to covid pressures. Guardian 2022 Jan 6. https://www.theguardian.com/society/2022/jan/06/nhs-trusts-england-critical-incidents-covid-pressures-omicron

2 NHS England. Emergency preparedness, resilience and response (EPRR). https://www.england.nhs.uk/ourwork/eprr/

3 Nuffield Trust. NHS performance summary: October-November 2021. https://www.nuffieldtrust.org.uk/news-item/nhs-performance-summary-october-november-2021

4 UK Government. Coronavirus (COVID-19) in the UK. https://coronavirus.data.gov.uk

$5 \quad$ NHS England. Urgent and emergency care daily situation reports 2021-22. Staff absences 29 November 2021 to 2 January 2022. https://www.england.nhs.uk/statistics/statistical-work-areas/uec-sitrep/urgent-and-emergency-care-daily-situation-reports-2021-22/

6 Mason R, Campbell D. Parts of NHS may be overwhelmed by Covid wave, admits Boris Johnson. Guardian 2022 Jan 4. https://www.theguardian.com/world/2022/jan/04/parts-of-nhs-may-beoverwhelmed-by-covid-wave-admits-boris-johnson

7 Dunn P, Allen L, Cameron G, Malhotra AM, Alderwick H. Covid-19 policy tracker. Health Foundation, 2020. https://www.health.org.uk/news-and-comment/charts-and-infographics/covid-19-policytracker

8 UK Government. COVID-19 response: spring 2021. https://www.gov.uk/government/publications/covid-19-response-spring-2021/covid-19-response-spring-2021

9 UK Government. Covid-19 response: autumn and winter plan 2021. https://www.gov.uk/government/publications/covid-19-response-autumn-and-winter-plan-2021/covid-19-response-autumnand-winter-plan-2021

10 UK Government. Slides, datasets, and transcripts to accompany coronavirus press conferences. https://www.gov.uk/government/collections/slides-and-datasets-to-accompany-coronaviruspress-conferences

11 Rosenbaum L. Facing covid-19 in Italy-ethics, logistics, and therapeutics on the epidemic's front line. N Engl J Med 2020;382:1873-5. doi: 10.1056/NEJMp2005492 pmid: 32187459

12 European Observatory on Health Systems and Policies. COVID-19 health system response monitor: how are countries reorganizing non-COVID-19 health care service delivery? 2020 https://eurohealthobservatory.who.int/monitors/hsrm/analyses/hsrm/how-are-countries-reorganizing-non-covid-19-health-care-service-delivery

13 OECD. Health at a glance: Europe 2020. https://www.oecd-ilibrary.org/social-issues-migrationhealth/health-at-a-glance-europe-2020_82129230-en

14 World Health Organization. Second round of the national pulse survey on continuity of essentia health services during the COVID-19 pandemic. https://www.who.int/publications/i/item/WHO2019-nCoV-EHS-continuity-survey-2021.1

15 NHS England. Consultant-led referral to treatment waiting times. https://www.england.nhs.uk/statistics/statistical-work-areas/rtt-waiting-times/

16 Klein R, Maybin J. Thinking about rationing. King's Fund, 2012.

17 Gershlick B, Charlesworth A. Health and social care workforce. Health Foundation, 2019 https://www.health.org.uk/publications/long-reads/health-and-social-care-workforce.

18 lacobucci G. Covid-19: NHS trusts declare "critical incidents" because of staff shortages. BMJ 2022;376:03. doi: 10.1136/bmj.03 pmid: 34983792

19 lacobucci G. Patients are at risk as NHS reaches unsafe "tipping point," leaders warn government. BMJ 2021;375:n2766. doi: 10.1136/bmj.n2766 pmid: 34764086

20 Campbell D, Sabbagh D, Devlin H. Military deployed at London hospitals due to Omicron staff shortages. Guardian 2022 Jan 7. https://www.theguardian.com/world/2022/jan/07/military-deployed-at-london-hospitals-due-to-omicron-staff-shortages

21 Moore A. 'Get a lift to hospital,' ambulance trust tells patients with suspected heart attacks. Health Serv /2022;4.https://www.hsj.co.uk/quality-and-performance/get-a-lift-to-hospital-ambulance-trust-tells-patients-with-suspected-heart-attacks/7031626.

22 Department of Health and Social Care. NHS constitution for England. https://www.gov.uk/government/publications/the-nhs-constitution-for-england

23 Gardner T, Fraser C. Longer waits, missing patients, and catching up: how is elective care in England coping with the continuing impact of COVID-19? 2021. https://www.health.org.uk/newsand-comment/charts-and-infographics/how-is-elective-care-coping-with-the-continuing-impactof-covid-19

24 O'Dowd A. NHS staff's stress levels rose last year as covid pandemic took its toll. BMJ 2021;372:n703. doi: 10.1136/bmj.n703 pmid: 33712446

25 House of Commons Health and Social Care Committee. Workforce burnout and resilience in the NHS and social care. 2021. https://committees.parliament.uk/publications/6158/documents/68766/default/

26 Greenberg N, Weston D, Hall C, Caulfield T, Williamson V, Fong K. Mental health of staff working in intensive care during Covid-19. Occup Med (Lond) 2021;71:62-7.

doi: 10.1093/occmed/kqaa220 pmid: 33434920
27 Barry J, Duxbury K, Gideon S. Ipsos Mori NHS polling. 2021. https://www.ipsos.com/ipsos-mori/enuk/8-10-think-nhs-coping-well-treating-coronavirus-patients-moment-only-just-over-half-saysame-other

28 Rocks S, Boccarini J, Charlesworth A, Idriss O, McConkey R, Rachet-Jacquet L. Health and social care funding projections 2021. Health Foundation, 2021. https://www.health.org.uk/publications/health-and-social-care-funding-projections-2021

29 OECD. OECD health statistics 2021. https://www.oecd.org/els/health-systems/health-data.htm

30 Sagan A, Webb E, Greer S, et al. Health systems resilience during covid-19: lessons for building back better. European Observatory on Health Systems and Policies, 2021. https://eurohealthobservatory.who.int/publications/i/health-systems-resilience-during-covid-19-lessons-for-buildingback-better

31 Dunn P, Allen L, Alarilla A, Grimm F, Humphries R, Alderwick H. Adult social care and covid-19 after the first wave: assessing the policy response in England. Health Foundation, 2021. https://www.health.org.uk/publications/reports/adult-social-care-and-covid-19-after-the-firstwave

32 Parker G, Barnes O. Tories applaud Boris Johnson for resisting more covid restrictions. Financial Times 2022 Jan 5. https:/www.ft.com/content/0422a535-b924-48ee-86b3-12eca7e3decf

This article is made freely available for personal use in accordance with BMJ's website terms and conditions for the duration of the covid-19 pandemic or until otherwise determined by BMJ. You may download and print the article for any lawful, non-commercial purpose (including text and data mining) provided that all copyright notices and trade marks are retained. 